\title{
Fusarium Species and their Association with Soybean Seed under Humid Tropical Conditions in Puerto Rico' ${ }^{1}$
}

\author{
P. R. Hepperly ${ }^{2}$ \\ ABSTRACT
}

Over $90 \%$ of all Fusarium isolates from 'Davis' soybeans in Corozal and Isabela, Puerto Rico, were identified as F. semitectum; 3 and $2 \%$ were identified as $F$. oxysporum and $F$. solani, respectively; and less than $1 \%$ each were identified as $F$. rigidusculum and $F$. episphaeria var. dimerum. $F$. semitectum comprised 32.6 and $24.8 \%$ of all fungal isolates from seed in Corozal and Isabela, respectively. F. semitectum infected soybean seed germinated $9.4 \%$ and $31.1 \%$ in seedlots from Corozal and Isabela, respectively. Seed infections of Improved Pelican soybeans by F. semitectum were first detected during full green bean stage. Frequency of infection increased rapidly at and after yellow pod stage. In laboratory studies, after pods were incubated 5 days at $95 \%$ RH and $27^{\circ} \mathrm{C}, F$. semitectum inoculated, wounded and inoculated, and nontreated detached full green pods showed 65,100 , and $9 \%$ seed viability losses, respectively. Lima bean pod borer (Etiella zinckenella) injury to soybean pods increased incidence of $F$. semitectum in intact seed and reduced seed germination and incidence of Phomopsis sp., compared to that found in noninjured pods. Naturally aborted soybean pods had a high incidence of $F$. semitectum $(85 \%)$ and low incidence (less than $10 \%$ ) of Collectotrichum dematium, Phomopsis sp., Botryodiploidia theobromae, and Alternaria tenuissima.

\section{INTRODUCTION}

Strong demand for high quality vegetable oil and protein has led to a dramatic surge in world soybean production during the 20th century. Bell (1) found that the world trade in soybeans increased $66 \%$ from 1973 to 1978 and that total world trade exceeded 35 million metric tons annually in 1978.

Soybeans have been widely used in temperate countries including those of North America, Europe and Eastern Asia. Nevertheless, many tropical regions, which are deficient in both protein and calories, neither use nor cultivate soybean.

To expand the use and production of soybeans in the tropics by the proper technology and applied research in solving problems in tropical soybean adaptation is a prime objective of the International Soybean Program (INTSOY) (9).

Soybean seed to be used for planting should be of a known genetic makeup, be free of or carry low levels of pests, and have high viability.

\footnotetext{
${ }^{1}$ Manuscript submitted to Editorial Board January 20, 1984.

${ }^{2}$ Assistant Professor, Department of Crop Protection, University of Puerto Rico, Mayagüez 00709. Work was partially supported by the United States Agency for International Development through the grant AID/CM/TA-G-73-50 and by the College of Agricultural Experiment Station.
} 
Difficulty in obtaining and maintaining high viability seed in hot humid tropical climates is a major factor limiting soybean production (20). To improve plant stands under tropical conditions, local systems for producing and certifying seed must be developed. These systems will be most successful when seeds can be screened to eliminate those with high incidence of serious pests (13). Therefore, seed pathology has a great potential in the applied agriculture of the tropics.

Over 66 fungi, 6 bacteria, and 8 viruses are reported seedborne in soybean (21). Although investigators have often studied the composite effect of seedborne microflora in reducing seed quality and viability, the individual influence of seed microflora components is often not known (13). Of all the microorganisms on soybean seed, Phomopsis sp., which is a major determinant of seed quality losses, is most clearly understood $(10,11,19)$. Ellis and Paschal (5) used Phomopsis sp. as an indicator of resistance to field deterioration of soybean seeds under tropical conditions. Besides Phomopsis, Fusarium and Cercospora have been found to be important in explaining seedlot viability differences in tropical soybeans (12). Compared to Phomopsis sp., Fusarium spp. have received little attention in soybean seed health studies (21).

Most studies on soybean seed pathology report neither the identification nor the relative frequency of Fusarium spp. (14, 15, 18). In Iowa, Nyvall (16) found up to $30 \%$ infection of soybean seed by F. roseum and F. tricinctum. In Delaware, Ferrant and Carroll (8) found high rates of F. oxysporum in seeds of soybean plants with Fusarium wilt. In India, Ram Nath et al. (17) reported the occurrence of $F$. oxysporum, $F$. solani, $F$. moniliforme, and $F$. semitectum in soybean seed.

There is conflicting evidence on the role of $F$. semitectum in soybean seed health in the New World Tropics. Dhingra (4) found that high incidence of $F$. semitectum in soybeans in Brazil was strongly associated with decreased soybean seed germination. In Puerto Rico, however, Ellis et al. (6) considered $F$. semitectum as saprophytic on soybean seed and of little importance to soybean seed health.

Considering this background, further study of the seedborne species of Fusarium in soybean was deemed important.

\section{MATERIALS AND METHODS}

Field experiments were conducted at the Corozal and Isabela Research Centers of the University of Puerto Rico College of Agriculture Experiment Station. Sites were typical of many humid tropical areas with high rainfall and highly leached acid soils of low inherent soil fertility. The Corozal site is approximately $300 \mathrm{~m}$ above sea level with a Corozal clay Ultisol of $\mathrm{pH} 4.5-5.5$, with an annual mean rainfall of $2,000 \mathrm{~mm}$ and a 
mean temperature of $25^{\circ} \mathrm{C}$. The Isabela site is approximately $50 \mathrm{~m}$ above sea level on a Coto clay, Oxisol, pH 5.0-6.0 an annual mean rainfall of $1500 \mathrm{~mm}$ and a mean temperature of $28^{\circ} \mathrm{C}$.

Certified Davis soybean seed were planted at both Corozal and Isabela in July 1978 and harvested in October of the same year. July is the driest month of the wet season in Puerto Rico; near maximum rainfall occur in August, September and October. Seeds were hand planted at a density of 30 seed per meter row with rows $0.75 \mathrm{~m}$ on center. Fields at each site consisted of 24 plots. Each plot had four rows $5 \mathrm{~m}$ long.

All plots were hand harvested at maturity $\left(\mathrm{R}_{8}\right)$ and threshed mechanically at approximately $12 \%$ moisture. A 100 -seed sample was placed on moistened cellulose (Kimpac) at $95 \% \mathrm{RH}$ and $27^{\circ} \mathrm{C}$ for 1 to 2 weeks. Rates of germination and microorganisms in seed were determined by visual counts and with the aid of the stereo- and compound microscopes.

Improved Pelican soybean seeds from a mid-July 1980 planting in Isabela, Puerto Rico were assayed for $F$. semitectum infections at various developmental stages. On October 30, November 7, 16, and 30, and December 10, plants were harvested at pod fill, full green pod, full yellow pod, harvest maturity and delayed harvest, respectively (7).

Pods from field grown Improved Pelican soybeans were harvested in full green bean stage November 7, 1980, from Isabela, Puerto Rico, and were inoculated in vitro with $F$. semitectum according to the procedures described by Hepperly and Sinclair for Phomopsis sp. (11). Surface treated detached pods ( $0.5 \% \mathrm{NaOCl}$ for 4 minutes) were inoculated with pure cultures of $F$. semitectum. Inoculum was prepared by scraping the surface of 10-day-old PDA cultures in $9 \mathrm{~cm}$ petri plates grown at $27^{\circ} \mathrm{C}$ in $15 \mathrm{ml}$ of sterile distilled water. The fungus suspension was then ground with mortar and pestle and inoculum was applied on the pod surface with a medicine dropper. Pods were inoculated over sites of the developing seeds directly without wounding or after previous wounding with a cluster of 500-gauge insect pins to rupture the pod surface. At each site approximately 0.07 to $0.08 \mathrm{ml}$ of inoculum was applied. Noninoculated pods served as controls. After treatment, pods were kept at $95 \% \mathrm{RH}$ and $27^{\circ}$ $\mathrm{C}$ for 5 days. They were then rated for lesion development, and seed isolations were made after surface desinfecting pods with $0.5 \% \mathrm{NaOCl}$ for 4 minutes. Seeds were plated on PDA and incubated for 7 days at $27^{\circ}$ C. Treatments included wounding alone, inoculation alone; wounding and inoculation; and no treatment. A randomized design with four replications was used. Each replication consisted of 50 pods.

In mid-June 1979 (full yellow bean stage) Forrest soybean pods were found drying down prematurely after invasion by lima bean borers. At nodes showing pod-borer damage an infested pod with a perforation and 
a healthy intact pod were harvested. A total of 200 nodes were sampled in all. Pods of each type were divided into four groups of 50 pods each for laboratory analyses. Seeds were removed by hand and only intact uneaten seeds were assayed. From each group of invaded and noninfested pods, 100 and 125 seeds, respectively, were randomly selected and surfacedisinfected with $0.5 \% \mathrm{NaOCl}$ for 4 minutes. Seeds were dried under sterile filtered air and then plated on sterile PDA. Seeds were incubated 7 days at $27^{\circ} \mathrm{C}$ after which time seed fungi and germination were determined.

Test isolations were made from Etiella zinckenella larvae of approximately $14 \mathrm{~mm}$ in length. Twenty larvae (about $1 \mathrm{~g}$ ) were killed by being merged in $70 \%$ ethyl alcohol for 1 minute. After a 4-minute disinfection $(0.5 \% \mathrm{NaOCl})$ larvae were aseptically ground in $10 \mathrm{ml}$ of sterile distilled. water by means of sterile mortar and pestle. Dilutions of $10^{-1}$ to $10^{-7}$ were tested by placing $1 \mathrm{ml}$ aliquots on $9 \mathrm{~cm}$ diameter sterile plastic plates filled with sterile PDA. Five plates were made for each dilution. In another test 20 larvae of the same size were killed and disinfected as previously described but then incubated whole on moist cellulose padding in $9 \mathrm{~cm}$ sterile plastic plates. Four larvae were plated on each of five plates which were incubated at $95 \% \mathrm{RH}$ and $27^{\circ} \mathrm{C}$ for 10 days.

In 1979 aborted pods from nine soybean cultivars (Buffalo, Cobb, Davis, Hardee Late Selection, IAC-2, Improved Pelican, Jupiter, Orba, and Ransom) were collected in mid-June from a mid-March planting at Isabela, Puerto Rico. From each cultivar 25 aborted pods were randomly selected and analyzed. Fungi present were examined directly under the stereo- and compound microscopes. Notes were taken on the species of fungi present on the aborted pods and their relative frequencies were determined.

\section{RESULTS AND DISCUSSION}

\section{F. Semictectum Incidence and Severity}

In Puerto Rico, F. semitectum appeared to be the second most common fungus on soybeans grown under humid conditions (table 1). In these assays, the fungus was highly associated with dead seed. More than $75 \%$ of $F$. semitectum infected seed was nonviable. These results support the conclusion that $F$. semitectum is an important and underestimated factor in soybean seed health in tropical and subtropical regions (4). Four other species of Fusarium ( $F$. oxysporum, $F$. solani, $F$. rigidusculum, and $F$. episphaeria var. dimerum) were all found at low incidences in these studies. 
TABLE 1.-Incidence of Fusarium semitectum and other seedborne mycoflora and their associations with dead seed in "Davis" soybeans produced under humid conditions in Corozal and Isabela ${ }^{1}$, Puerto Rico

\begin{tabular}{|c|c|c|c|c|}
\hline \multirow{3}{*}{ Fungus } & \multicolumn{4}{|c|}{ Percentage Seed } \\
\hline & \multicolumn{2}{|c|}{ Incidence } & \multicolumn{2}{|c|}{ Lethality ${ }^{2}$} \\
\hline & Corozal & Isabela & Corozal & Isabela \\
\hline F. semitectum ${ }^{3}$ & $23.2 \pm 2.9^{4}$ & $24.7 \pm 2.5$ & $90.6 \pm 2.0$ & $68.9 \pm 4.4$ \\
\hline Phomopsis sp. ${ }^{5}$ & $34.3 \pm 3.0$ & $33.1 \pm 3.2$ & $75.2 \pm 4.3$ & $71.2 \pm 3.6$ \\
\hline Cercospora kikuchii & $0.6 \pm 0.3$ & $30.8 \pm 3.1$ & $24.0 \pm 2.7$ & $30.0 \pm 2.4$ \\
\hline Botryodiploidia theobromae & $2.8 \pm 0.8$ & $1.0 \pm 0.3$ & $97.7 \pm 2.2$ & $100.0 \pm 0.0$ \\
\hline Colletotrichum dematium & $2.8 \pm 1.0$ & $7.8 \pm 2.0$ & $90.1 \pm 9.9$ & $82.8 \pm 5.9$ \\
\hline Rhizoctonia solani & $0.3 \pm 0.2$ & $1.7 \pm 1.0$ & $100.0 \pm 0.0$ & $92.5 \pm 2.7$ \\
\hline Corynespora cassicola & $7.2 \pm 1.2$ & $0.2 \pm 0.1$ & $94.0 \pm 8.2$ & $100.0 \pm 0.0$ \\
\hline
\end{tabular}

${ }^{1}$ Soybean seed germination at Corozal and Isabela was 35.5 and $43.6 \%$, respectively.

${ }^{2}$ Lethality or the percentage of infected seeds which were nonviable was calculated using the formula:

$$
\text { Lethality }=\frac{\text { No. of dead seed infected with a fungus }}{\text { Total no. of seeds infected with same }} \times 100
$$

${ }^{3} \mathrm{~F}$. semitectum constituted 32.6 and $24.8 \%$ of the observed fungi from seed at Corozal and Isabela, respectively.

${ }^{4}$ Means are based on 24100 -seed lots which were analyzed for germination and mycoflora on moist cellulose pads at $37^{\circ} \mathrm{C}$ and $95 \% \mathrm{RH}$ for 7 to 14 days. Means are expressed with their corresponding standard error.

${ }^{5}$ Phomopsis sp. constitued 48.1 and $33.0 \%$ of the observed fungi from seed at Corozal and Isabela, respectively.

TABLE 2.-The effects of pod wounding and Fusarium semitectum inoculation on pod lesions, seed infections, and seed germination of "Improved Pelican" soybeans

\begin{tabular}{lccccc}
\hline \multirow{2}{*}{ Pod Treatment } & \multicolumn{4}{c}{ Percentage } \\
\cline { 2 - 5 } & $\begin{array}{c}\text { Pods with } \\
\text { Lesions }\end{array}$ & $\begin{array}{c}\text { F. semitectum } \\
\text { in Seeds }\end{array}$ & Germination & $\begin{array}{c}\text { Viability } \\
\text { Loss }\end{array}$ \\
\hline Nonwounded Noninoculated & $5^{2}$ & 2 & 91 & 0 \\
Wounded $^{3}$ Noninoculated & 29 & 0 & 80 & 14 \\
Nonwounded Inoculated $^{4}$ & 75 & 41 & 32 & 62 \\
Wounded Inoculated & 100 & 88 & 0 & 100 \\
\hline
\end{tabular}

${ }^{1}$ Necrotic areas greater than $4 \mathrm{~mm}^{2}$ were counted as pod lesions after 5 days at $95 \% \mathrm{RH}$ and $27^{\circ} \mathrm{C}$.

${ }^{2}$ Based on 4 groups of 50 pods each; seeds were surface-treated and plated on agar plates (PDA).

${ }^{3}$ Wounds were made by a cluster of 5 insect pins (gauge 00) used to rupture the pod surface only.

${ }^{4}$ To inoculate $F$. semitectum surface mycelium from 1-week-old PDA, cultures were harvested by scraping with $15 \mathrm{ml}$ water. Mycelium was ground with a mortar and pestle and the inoculum solution $(0.07-0.08 \mathrm{ml})$ was applied on the pod surface over each developing seed. 


\section{Pathogenicity}

In vitro inoculation of Improved Pelican soybean pods with $F$. semitectum resulted in notable increases in $F$. semitectum seed infection and notable decreases in seed viability (table 2). Artificial wounding of soybean pods was not a requirement for invasion of pods and seed by $F$. semitectum, but it did increase its severity and incidence. Although Ellis et al. (6) report $F$. semitectum on soybean seed as a nonpathogenic saprophyte, these studies reveal the parasitic and pathogenic nature of $F$. semitectum on senescing soybean pods in the humid tropics.

TABLE 3.-Frequencies of Fusarium semitectum, total fungal seed infections, and germination in "Improved Pelican" soybean seeds at various seed development and maturation stages

\begin{tabular}{lcccc}
\hline \multicolumn{1}{c}{$\begin{array}{c}\text { Developmental } \\
\text { stage }\end{array}$} & \multicolumn{4}{c}{ Percentage } \\
\cline { 2 - 5 } & $\begin{array}{c}\text { Fusarium } \\
\text { semitectum }\end{array}$ & Total fungi & $\begin{array}{c}\text { F. semitectum } \\
\text { Total fungi }\end{array}$ & Germination \\
\hline $\begin{array}{l}\text { Pod-fill } \\
\text { October 30 (R5) }\end{array}$ & $0^{2}$ & 3 & 0 & 95 \\
$\begin{array}{l}\text { Full green pod } \\
\text { November 7 (R6) }\end{array}$ & 4 & 23 & 17 & 90 \\
$\begin{array}{l}\text { Full yellow pod } \\
\text { November 16 (R7) }\end{array}$ & 9 & 37 & 24 & 88 \\
$\begin{array}{l}\text { Harvest maturity } \\
\text { November 30 (R8) } \\
\text { Delayed harvest }\end{array}$ & 19 & 60 & 32 & 45 \\
December 10 & 27 & 100 & 27 & 17 \\
\hline
\end{tabular}

${ }^{1}$ Maturity based on Fehr et al.

${ }^{2}$ Based on 4 replications 100 -seed each.

\section{Developmental Stages}

$F$. semitectum was first isolated from soybeans when plants were in the full green pod stage (table 3). At the yellow pod stage and after this stage, there was a notable increase in seed infection and a corresponding decrease in seed germination. Timing of $F$. semitectum infection in soybean seed appears to be similar to that of Phomopsis sp. (11).

\section{Association with Pod-borers}

Lima bean pod borer damage on soybeans was associated with increased $F$. semitectum incidence in the intact seed from damaged pods. Also reduced levels of seed germination and Phomopsis sp. incidence compared to those of seed from intact non-invaded pods (table 4). F. semitectum was detected on surface disinfected larvae incubated whole on cellulose pads but not in dilution plates. Pod-borer damage appears to be a significant factor in increasing $F$. semitectum incidence and 
severity. Pod damage by corn ear worm and bean leaf beetles in soybeans increases pod and seed colonization by Phomopsis sp. and Alternaria sp. ${ }^{3}$ The exact nature of the lima bean borer and $F$. semitectum relationship should be studied further. F. semitectum is reported as a pathogen of certain leaf eating insects (2).

Besides $F$. semitectum relationships with insects, determination of its possible toxicity to domestic animals will be important for understanding the extent of $F$. semitectum losses in the tropics. Many Fusarium species are known producers of mycotoxins causing poor health of animals and humans.

TABLE 4.-The effect of pod-borer (Etiella zinckenella Treitschke) on seed germination and mycoflora of "Forrest" soybeans (Glycine max)

\begin{tabular}{lcccc}
\hline \multirow{2}{*}{ Seed origin } & \multicolumn{4}{c}{ Percentage } \\
\cline { 2 - 5 } & Germination & F. semitectum & Phomopsis sp. & Total fungi \\
\hline Pod borer & 12.7 & 27.0 & 16.0 & 58.0 \\
Invaded pods $^{1}$ & 42.0 & 5.8 & 54.1 & 68.0 \\
Intact pods $^{2}$ & $* * 3$ & $* *$ & $* *$ & NS $^{4}$ \\
\hline
\end{tabular}

\footnotetext{
${ }^{1}$ Based on 4 groups of 50 pod-borer invaded pods assaying only uneaten seeds; approximately 100 seed per replication.

${ }^{2}$ Based on seed from 4 groups of 50 pods each, not invaded by pod borer, approximately 125 seed per replication.

${ }^{3}$ Significant difference at $\mathrm{P}=0.01$ using an unpaired $t$-test.

${ }^{4}$ Nonsignificant difference at $\mathrm{P}=0.05$ based on unpaired $t$-test.
}

\section{Association with Aborted Pods}

Soybeans naturally abort the majority of their potential reproductive structures (22). In this study $85 \%$ of aborted pods were found colonized by $F$. semitectum. Among the same pods, Colletotrichum dematium, Phomopsis sp., Botryodiplodia theobromae, and Alternaria tenuissima were found on $7,3,3$, and $2 \%$, respectively. Aborted pods appear to be a significant source of $F$. semitectum inoculum and they probably contribute to the invasion of mature pods and seed.

\section{RESUMEN}

Más del $90 \%$ de las aislaciones de Fusarium en semillas de soya 'Davis' cosechadas en Corozal e Isabela, Puerto Rico, se identificaron como F. semitectum; 3 y $2 \%$ de las mismas aislaciones se identificaron como $F$. oxysporum y F. solani, respectivamente; y menos de $1 \%$ como F. rigidusculum y $F$. episphaeria var. dimerum. La incidencia de $F$. semitectum llegó a $32.6 \%$ de todas las aislaciones de hongos en Corozal y $24.8 \%$ en

\footnotetext{
${ }^{3}$ B. J. Short, personal communication.
} 
Isabela. Se encontraron las primeras infecciones internas en semillas de soya 'Improved Pelican' cuando las vainas estaban hechas pero todavía verdes. La incidencia de infección en la semilla aumentó notablemente en vainas amarillas y en etapas más avanzadas. Vainas hechas pero verdes se cosecharon e inocularon con F. semitectum. Se notaron pérdidas en la viabilidad de la semilla cuando las vainas inoculadas se incubaron por 5 días a $95 \% \mathrm{HR}$ y $27^{\circ} \mathrm{C}$. Las semillas de las vainas inoculadas perdieron $65 \%$ de su viabilidad mientras que las de las vainas inoculadas sobre heridas artificiales perdieron la viabilidad totalmente. El barrenador de la vaina de la haba (Etiella zinckenella) aumentó la infección de semillas por F. semitectum y disminuyó la germinación y la infección por Phomopsis sp. En vainas abortadas se observó una elevada incidencia (85\%) de $F$. semitectum. Collectotrichum dematium, Phomopsis sp., Botryodiploidia theobromae y Alternaria tenuissima también colonizaron las vainas abortadas, pero a incidencias menores de $8 \%$ cada uno.

\section{LITERATURE CITED}

1. Bell, R. E., 1980. Soybeans in World Trade: in World Soybean Research Conference II. Fredick T. Corbin, Ed. Westview Press, Boulder, Colorado.

2. Booth, C., 1978. F. semitectum. CMI Descriptions of Pathogenic Fungi and Bacteria No 573, Commonwealth Mycological Institute, Kew, England.

3. Crittenden, H. W., 1968. Increase of Diaporthe phaseolorum var. sojae on soybean pods due to corn earworm, Phytopathology 58: 883 (Abstr.).

4. Dhingra, O. D. and da Silva, J. F., 1978. Effect of weed control on the internally seedborne fungi in soybean seed, Plant Dis. Rep. 62: 513-16.

5. Ellis, M. A. and Paschal II, E. H., 1978. Variation in seed quality of tropically grown soybeans, Crop Sci. 18: 837-40.

6. Powell, P. E. and Sinclair, J. B., 1979. Internally seedborne fungi of soybean in Puerto Rico and their effect on seed germination and field emergence, Trop. Agric. 56: 17174.

7. Fehr, W. R., Caviness, C. E., Burmood, D. T. and Pennington, J. S., 1971. Stage of development descriptions for soybean, Crop Sci. 11: 929-32.

8. Ferrant, N. P. and Carrol, R. B., 1981. Fusarium wilt of soybean in Delaware, Plant Dis, 65: 596-99.

9. Goodman, R. M., Sinclair, J. B. and Hepperly, P. R., 1981. Plant pathology and the International Soybean Progràm (INTSOY), Plant Dis. 65: 214-74.

10. Hepperly, P. R. and Sinclair, J. B., 1978. Quality losses in Phomopsis-infected soybean seeds, Phytopathology 68: 1684-87.

11. — and — 1980. Detached pods for studies of Phomopsis sojae pod and seed colonization, J. Agric. Univ. P. R. 64 (3): 330-37.

12. — and - 1981. Relationships among Cercospora kikuchï, other mycoflora, and germination of soybeans in Puerto Rico and Illinois, Plant Dis. 65: 130-32.

13. McGee, D. C., 1981. Seed pathology: its place in modern seed production, Plant Dis. 65: 638-42.

14. — Brandt, C. L. and Burris, J. S., 1980. Seed mycoflora of soybeans relative to fungal interactions, seedling emergence, and carry over of pathogens to subsequent crops, Phytopathology 70: 615-17. 
15. Nicholson, J. F. and Sinclair, J. B., 1973. Effect of planting date, storage conditions, and seedborne fungi on soybean seed quality. Plant Dis. Rep. 57: 770-74.

16. Nyvall, R. F,, 1974. Fusarium species in pods and seeds of soybeans. Proc. Am. Phytopathol. Soc. 1: 40 (Abstr.).

17. Ram Nath, P., Neergaard, P. and Mathur, S. B., 1970. Identification of Fusarium species on seeds as they occur in the blotter test. Proc. Int. Seed Test Assoc. 35: 12144.

18. Roy, K. W. and Abney, T. S., 1976. Fungal colonization of soybean pods and seeds, Proc. Am. Phytopathol. Soc. 2: 89 (Abstr.).

19. Schmitthenner, A. F. and Kmetz, K. T., 1980. Role of Phomopsis sp. in the soybean seed rot problem: in World Soybean Research Conference II. F. T. Corbin, Ed, Westview Press, Boulder, Colorado.

20. Sinclair, J. B. and Jackobs, J. A., Eds, 1982. Soybean Seed Quality and Stand Establishment. College of Agriculture, Univ. of Illinois, Urbana. INTSOY 22. 206 pp.

21. — and Shurtleff, M. C., Eds, 1975. Compendium of Soybean Diseases. Am. Phytopathol. Soc., St. Paul, Minnesota.

22. Sinha, S. K., 1977. Physiological aspects of yield improvement in grain legumes: in Food Legumes Crops: Improvement and Production. FAO Plant Production and Protection Paper 9. FAO, Via delle Terme Caracalla, Rome, Italy. 